\title{
STRATEGI DINAS KOPERASI, UMKM, PERDAGANGAN DAN PERINDUSTRIAN DALAM PENATAAN PEDAGANG KAKI LIMA DI JALAN KAPTEN HARUN KABIR KOTA SUKABUMI
}

\author{
Shilvi Septiani ${ }^{1}$, Tuah Nur $^{2}$, \& Dian Purwanti ${ }^{3}$ \\ ${ }^{1}$ Program Studi Administrasi Publik Universitas Muhammadiyah Sukabumi \\ Email: shilvisep97@gmail.com \\ ${ }^{2}$ Universitas Muhammadiyah Sukabumi \\ Email: gem_nur@yahoo.co.id \\ ${ }^{3}$ Universitas Muhammadiyah Sukabumi \\ Email:purwantidian75@yahoo.com
}

\begin{abstract}
Abstrak
Penelitian ini bertujuan untuk mengetahui bagaimana strategi penataan pedagang kaki lima di Jalan Kapten Harun Kabir Kota Sukabumi. Kesemerawutan pedagang kaki lima yang ada di Jalan Kapten Hatun Kabir merupakan permasalahan yang membutuhkan penanganan agar tertata, tertib dan nyaman. Metode yang digunakan dalam penelitian ini adalah metode penelitian kualitatif. Hasil penelitian menemukan bahwa penataan PKL yang berada di Jalan Kapten Harun Kabir Kota Sukabumi belum dilakukan secara merata dan optimal, masih banyak kekurangan-kerungan yang terjadi. Oleh karena itu kekurangan-kekurangan ini harus segera di tutupi agar penataan PKL dapat berjalan dengan optimal.
\end{abstract}

Kata Kunci: manajemen strategi, penataan, pedagang kaki lima.

\begin{abstract}
This study aims to determine how the strategy of structuring street vendors in Jalan Captain Harun Kabir Sukabumi City. The complexity of street vendors in Jalan Kapten Hatun Kabir is a problem that requires handling to be orderly, orderly and comfortable. The method used in this study is a qualitative research method. The results of the study found that the arrangement of street vendors who were in Jalan Captain Harun Kabir Sukabumi City had not been done evenly and optimally, there were still many deficiencies that occurred. Therefore, these deficiencies must be covered immediately so that the arrangement of street vendors can run optimally.
\end{abstract}

Keywords: strategy management, structuring, street vendors.

\section{A. PENDAHULUAN}

Menurut Peraturan Daerah No. 10 Tahun 2013 Kota Sukabumi, Pedagang kaki lima yang selanjutnya disingkat dengan PKL adalah pelaku usaha yang melakukan usaha perdagangan dengan menggunakan sarana usaha bergerak maupun tidak bergerak, menggunakan prasarana kota, fasilitas sosial, fasilitas umum, lahan dan bangunan milik pemerintah dan atau swasta yang bersifat sementara atau tidak tetap. 
PKL merupakan jenis usaha yang bermodal kecil, khususnya bagi mereka yang golongan ekonomi menengah ke bawah. Sehingga mereka membuka usaha sendiri dengan bermodal kecil Hal ini dilakukan untuk kelangsungan hidup dan untuk memenuhi kebutuhan pokok sehari-hari di tengah keras dan ketatnya persaingan hidup di kota.

PKL biasanya berjualan di tempat-tempat umum atau di tempat keramaian. PKL sering kita jumpai berjualan di pinggir jalan atau trotoar. Hal ini dapat menimbulkan masalah karena pada dasarnya trotoar itu di peruntukan bagi pejalan kaki bukan untuk berjualan. Hal ini juga dapat mengganggu kenyamanan dan ketertiban khusunya bagi pejalan kaki. Bahkan ada pula PKL yang berjualan di badan jalan yang dapat menggangu arus lalu lintas sehingga menyebabkan kesemrawutan.

Kota sukabumi juga tak luput dari permasalahan diatas, hal ini dapat dilihat dari adanya kelompok-kelompok PKL yang berjualan di koridor utama jalan. PKL pada umumnya menempati badan jalan, dan trotoar. Dapat kita jumpai di beberapa ruas jalan trotoar di Kota Sukabumi banyak dijadikan tempat berjualan PKL. Banyaknya PKL di Kota Sukabumi memerlukan suatu strategi untuk mengaturnya agar tidak menggangu ketertiban umum. Diperlukan kebijakan agar PKL tidak seenaknya berjualan di tempat yang tidak semestinya. Fungsi kebijakan itu untuk mengatur dan menata PKL agar tertib dan berjualan di tempat yang disediakan oleh pemerintah. Dalam menjalankan kebijakan Perda Kota Sukabumi No. 10 Tahun 2013 tentang Penataan dan Pemberdayaan Pedagang Kaki Lima, Instasi yag terkait untuk menangai PKL adalah Dinas Koperasi, UMKM, Perdagangan dan Perindustrian Kota Sukabumi yang dibantu oleh Dinas Sat Pol PP.

Penataan dan pengaturan PKL di Kota Sukabumi belum terlaksana dengan baik. Karena sampai saat ini upaya pemerintah Kota Sukabumi khususnya untuk penataan PKL belum mampu mewadahi kegiatan perdagangan dengan maksimal. Sampai saat ini belum ada upaya yang optimal dari pemerintah khususnya instansi terkait belum mampu menyediakan lokasi yang tepat untuk PKL yang ada di Kota Sukabumi. Maka dari itu disini pemerintah mempunyai tugas memberikan suatu strategi untuk menata PKL yang berada di sekitaran Jalan Harun Kabir.

Menurut Winardi (2003), strategi adalah sebagai sebuah rencana atau semacam arah untuk mencapai tujuan, tetapi untuk mencapai tujuan tersebut, strategi tidak berfungsi sebagai peta jalan yang hanya menunjukan arah jalan saja, melainkan harus mampu menunjukan taktik operasionalnya. Strategi sebagai bagian terpadu dari suatu rencana (plan), dimana 
rencana merupakan produk dari perencanaan (planning) yang pada akhirnya perencanaan adalah salah satu fungsi dasar dari manajemen.

Dalam hal ini peneliti akan mengambil studi kasus terkait PKL yang berada dijalan Kapten Harun Kabir Kota Sukabumi. Karena Jalan Kapten Harun Kabir merupakan salah satu jalan yang strategis yang berada di pusat Kota Sukabumi jalan tersebut merupakan jalan yang banyak dilalui pejalan kaki. Jalan Kapten Harun Kabir merupakan daerah pusat perbelanjaan. Banyaknya masyarakat yang berbelanja atau sekedar berjalan-jalan di depan toko dan pinggir-pinggir trotoar.
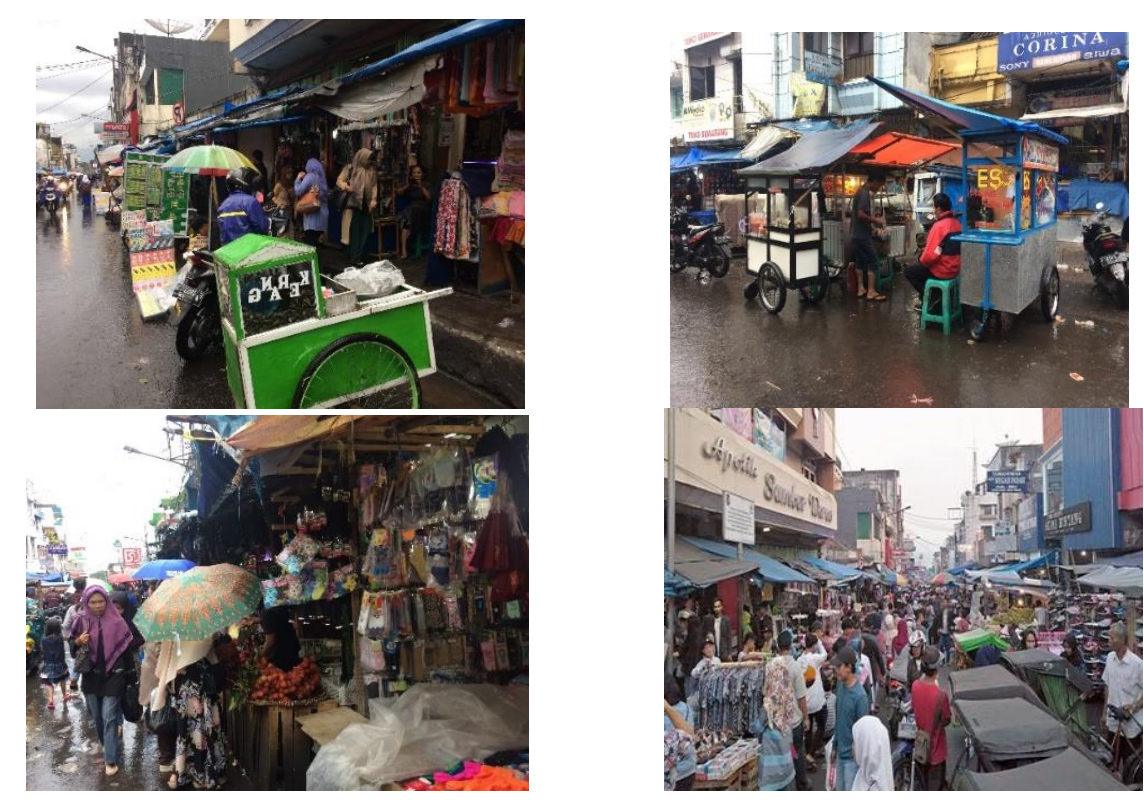

Gambar 1 Pedagang Kaki Lima Jalan Kapten Harun Kabir Sumber: Penelitian (2019)

Dari gambar tersebut tampak kesemerawutan PKL yang berada dijalan Kapten Harun Kabir yang dapat menggangu pejalan kaki akibat beralih fungsinya trotoar menjadi tempat berjualan. Hal ini merugikan bagi pejalan kaki. Banyaknya PKL yang berjualan hingga ke badan jalan, tidak hanya menggangu pejalan kaki, tetapi juga dapat menimbulkan kepadatan jalan dan kemacetan lalu lintas. PKL yang berjualan dibadan jalan sangat berbahaya dan bisa menjadi salah satu penyebab kecelakaan, karena jalan Kapten Harun Kabir selain banyak dilalui oleh pejalan kaki juga banyak dilalui kendaraan khususnya roda dua. Kesemerawutan PKL juga dapat kita rasakan pada hari-hari libur, seperti hari sabtu dan minggu, dimana banyak pejalan kaki yang melalui tersebut untuk berbelanja di pusat kota. 
Berbagai penelitian telah dilakukan terkait pedagang kaki lima, adanya peelitian terdahulu pada pembahsan ini guna untuk membandingkan kajian-kajian menganai penataan pedagang kaki lima, seperti Nursamsi Dwi Safitri (2015), yang menunjukan bahwa kebijakan penataan pedagang kaki lima dianggap berhasil karena mampu merelokasi pedagang kaki lima ketempat yang lebih baik dan meningkatkan pedapatan pedagang kaki lima sekaligus menjadi tempat hiburan bagi masyarakat. Sementara itu penelitian selanjutnya dilakukan oleh Mirna Nurlaili Syawalia (2018), menunjukan bahwa kebijakan penataan dan pemberdayaan pedagang kaki lima di Kota Sukabumi belum disosialisasikan dengan optimal sehingga masih banyak PKL yang belum mengetahui Perda No. 10 tahun 2013.

Tujuan dari penelitian ini adalah untuk mengetahui strategi Dinas Koperasi, UMKM, Perindustrian dan Perdagangan Kota Sukabumi dalam Penataan Pedagang Kaki Lima, khususnya Penataan PKL yang berada di Jalan Kapten Harun Kabir, serta untuk mengetahui faktor pendukung dan penghambat dalam melaksanakan strategi penataan pedagang kaki lima yang berada di Jalan Kapten Harun Kabir.

\section{B. KAJIAN PUSTAKA}

\section{Manajemen Strategi}

Manajemen strategi adalah serangkaian pengambilan keputusan yang bersifat mendasar dan menyeluruh, disertai penetapan cara melaksanakannya yang dibuat oleh pimpinan dan diimplementasikan oleh seluruh jajaran didalam suatu organisasi untuk mencapai tujuan Organisasi tersebut (Siagian, 2018).

Menurut Siagian (2018) bahwa manajemen strategik memiliki beberapa dimensi atau bersifat multidimensional. Dimensi-dimensi yang dimaksud adalah:

a. Dimensi Keterlibatan Manajemen Puncak

Salah satu sifat keputusan manajemen strategik ialah bahwa keputusan tersebut menyangkut seluruh segi organisasi. Karena sifat yang demikian, keterlibatan manajemen puncak bukan hanya tidak dapat dielakkan, akan tetapi bahkan merupakan suatu keharusan.

b. Dimensi alokasi dana, sarana dan prasarana

Suatu hal yang lumrah terjadi dalam suatu organisasi, baik yang kecil maupun yang besar, ialah bahwa para manajer dan karyawan yang bekerja pada satu satuan kerja tertentu cenderung merasa bahwa satuan kerja tempat merka berkaryalah yang terpenting. 
c. Dimenasi Waktu Keputusan Strategik

Salah satu ciri keputusan strategik adalah jangkauan waktunya yang relatif jauh kedepan, apakah itu lima tahun atau sepuluh tahun, bahkan bisa lebih. Penting untuk diperhatikan bahwa sekali manajemen puncak membuat keputusan strategic, atas dasar keputusan ituah citra organisasi diciptakan dan dipelihara.

d. Dimensi Orientasi Masa Depan

Disini sebuah organisasi membutuhkan seorang manajerial handal yang memiliki sikap antisipatif dan proaktif. Karena dengan sikap yang antisifatif dan proaktif, manajemen akan lebih siap menghadapi tanggapan perubahan yang akan terjadi dan tidak akan dihadapkan pada situasi "dadakan".

e. Dimensi Isu Strategik yang Multifaset

Kiranya penting untuk menekankan bahwa keputusan stratejik biasanya menjangkau semua komponen atau unsur organisasi, baik dalam ari dana, sarana, dan prasarana, tenaga kerja maupun dalam arti satuan-satuan kerja yang terdapat dalam organisasi dengan nomenklatur apapun satuan-satuan kerja.

f. Dimensi Lingkungan Eksternal

Suatu oraganisasi biasanya mempengaruhi lingkungannya dan pasti dipengaruhi oleh kondisi eksternal yang faktor-faktor umumnya berada diluar kendali organisasi yang bersangkutan. Untuk itu agar organisasi berhasil meraih keberhasilan yang didambakannya dimasa depan faktor-faktor ekternal tersebut harus diperhitungkan dengan matang.

\section{Penataan Pedagang Kaki Lima}

Dalam pasal 1 angka 5 Undang-Undang Nomor 26 tahun 2007 tentang penataan ruang, penataan ruang adalah suatu sistem proses perencanaan tata ruang, pemanfaatan tata ruang dan pengendalian pemanfaatan ruang. Pedagang kaki lima adalah pedagang yang menggunakan gerobak beroda. Jika roda gerobak ditambahkan dengan kaki pedagang, maka berjumlah lima, maka disebutlah pedagang kaki lima atau PKL (Permadi, 2007).

\section{METODE PENELITIAN}

Penelitian ini menggunakan pendekatan kualitatif deskriptif dengan konsep studi kasus. Metode penelitian Kualitatif sering disebut metode penelitian naturalistic karena penelitiannya dilakukan pada kondisi yang alamiah (natural setting) (Sugiyono, 2018). 
Dalam penentuan informan menggunakan purposive sampling yaitu sesuai dengan tujuan dan kegunaan penelitian. Ditentukan 8 informan dalam pengambilan data dan informasi yang dibutuhkan. Adapun metode pengambilan data yang digunakan yaitu, observasi, wawancara dan dokumentasi. Untuk tahap validitasi data dengan menggunakan triangulasi sumber, waktu dan teknik. Sedangkan untuk menganalisis data dengan mengumpulkan data sampai tahap penyajian dan membuat kesimpulan supaya dapat dipahami.

\section{HASIL DAN PEMBAHASAN}

\section{Keterlibatan Manajemen Puncak}

Salah satu sifat keputusan strategi adalah bahwa keputusan tersebut menyangkut seluruh segi organisasi. Karena sifat yang demikian, keterlibatan manajemen puncak bukan hanya tidak dapat dielakan, akan tetapi bahkan merupakan suatu keharusan. Dikatakan demikian karena hanya pada manajemen puncaklah akan tampak segala bentuk implikasi dan ramifikasi berbagai tantangan dan tuntutan lingkungan internal dan eksternal yang sangat tidak munkin terlihat oleh para manajer tingkat yang lebih rendah. Keterlibatan dari manajemen puncak disini adalah bagaimana peran dari manajemen puncak atau pemimpin sebagai pemangku kekuasaan yang mempunyai suatu kebijakan dan wewenang. Dalam penataan pedagang kaki lima khususnya di jalan kapten harun kabir membutuhkan peran dari manajemen puncak. Dalam studi dan penelitian ini manajemen puncak yang dimaksud adalah pemerintah daerah kota sukabumi yang mana tugas, wewenang serta kebijakan terkait penataan pedagang kaki lima berada dibawah naungan Dinas Koperasi UMKM, Perdagangan dan Perindustrian Kota Sukabumi dan Dinas SatpolPP Kota Sukabumi. Keterlibatan manajemen puncak ini memang sangat penting perannya dalam penataan pedagang kaki lima khususnya yang ada dijalan kapten harun kabir.

Keterlibatan dari manajemen terkait strategi penataan itu ada, keterlibatannya manajemen puncak disini sebagai yang mempunyai kebijakan dan wewenang terkait penataan pedagang kaki lima. Dalam melakukan tugas ini menjadi tugas pemerintah daerah yang dibantu oleh dinas-dinas terkait sesuai dengan tugas, pokok dan fungsinya. Dalam strategi penataan pedagang kaki lima tentu tidak hanyak satu instant yang menjalankan tetapi ada instansi yang saling berkaitan. Dalam melaksanakan tugas strategi penataan pedagang kaki lima ini ada di dalam bidang perdagangan pada Dinas Koperasi, UMKM, Perdagangan dan Perindustrian dan juga dibantu oleh Dinas SatPol PP pada bidang keamanan ketertiban dan perlindungan masyarakat. instansi yang terkait dalam melaksakan strategi penataan ini ada 
Dinas Koperasi, UMKM, Perdagangan dan Perindustrian dalam penataan pedagang kaki lima ini ada di UPT Bidang Perdagang yang berjumlah 14 sumber daya manusia. Selain Dinas Koperasi, UMKM, Perdagangan dan Perindustrian instansi terkait lain yaitu Dinas SatPol PP dalam penataan pedagang kaki lima ini ada dalam bidang 2 bidang yang pertama bidang penegakan perda dan sumbedaya aparatur dan bidang keamanan ketertiban dan perlindungan masyarakat. Untuk jumlah sumber daya manusianya sendiri yang melaksaknakan penindikan, pengaturan dan pengawasan yang ada dilapangan berjumlah 150 orang dan dibagi menjadi beberapa regu setiap regunya dibagi menjadi 23 orang. Sementara itu pernyataan dari informan pedagang dan masyarakat kurang mengetahui dinas mana yang bersangkutan untuk mengatur dan menata pedagang kaki lima yang ada di Jalan Kapten Harun Kabir, merka hanya mengetahu bahwa SatPol PP salah satu instansi terkait untuk mengatur semua itu.

Untuk mengetahui permasalahan apa saja yang terjadi agar bisa menjadi bahan evaluasi kedepannya tentu instansi juga selalu melakukan pengawasan dan pengevaluasian terkait perencanaan strategi penataan pedagang kaki lima khususnya yang berada di Jalan Kapten Harun Kabir. Dapat dilihat pula dari pernyataan-pernyataan diatas bahwa pengawasan dan pengevaluasian iu telah dilaksanakan namun pada kenyataanya bentuk evaluasi itu belum terlihat secara optimal untuk menangai kesemerawutan yang ada dan kurangnya sikap antisipasi dari pihak instansi dan juga ketegasan dalam penegakan aturan. Adanya sikap acuh tak acuh yang menjadi kenyataan di lapangan dari instansi terkait untuk menangani atau membuat strategi masih belum optimal. Dari hasil pernyataan diatas juga dapat kita bandingkan dengan fenomena masalah diawal kurangnyya pengontrola dan penindakan yang optimal itu masih terjadi sebab dapat dilihat dari pernyataan dari instasi baik diskopdagrin maupun sat pol pp itu berada di sumberdaya yang kurang dalam mengatur dan menindak pkl agar lebih optimal. Akan tetapi dari keseluruhan pernyataan bahwa evalusi dan pengwasan itu memang sudah dan selalu dilakukan.

\section{Alokasi Dana, Sarana dan Prasarana.}

Alokasi dana untuk strategi penataan pedagang kaki lima itu memang ada anggrannya untuk membiayai pembangunan relokasi, pembuatan seperti fasilitas gerobak, tenan atau lapak berjualan serta uang transportasi untuk pembawaan barang pedagang yang melakukan relokasi. Terkaian sarana pemerintah juga berupaya menyediakan sarana untuk pedagang kaki lima namun bisa dilihat dari hasil wawancara bahwa sarana yang diberikan belum secara khusus diperuntukan untuk pedagang yang beda di Jalah Harun Kabir. pemeritah sendiri tentu 
telah disediakan dan dianggarkan dana tersebut ada untuk membuat suatu sarana dan prasana para pedagang yang membutuhkan. Namun pernyataan tersebut belum diketahui oleh masyarakat khususnya para pedagang kaki lima yang berada di Jalan Kapten Harun Kabir kurang mengatahui adanya dana untuk sarana pedagang, yang mereka tahu dana itu kemungkinan digunkan untuk membuat atau pun membangun pasar. Dalam Perda No. 10 tahun 2013 dalam pasal 35 bahwa biaya yang didapatkan untuk pelaksanaan penataan pkl bersumber dari anggaran pendapatan dan belanja negara, anggaran pendapatan dan belanja daerah provinsi, anggaran pendapatan dan belanja daerah dan lain-lain sumber pendapatan yang sah dan tidak meningkat.

Sarana yang diberikan masih kepada mereka yang mempunyai usaha di tempat-tempat yang sudah tertata seperti di temapat kuliner selamat. pemerintah daerah sendiri telah menyediakan prasaran seperti disediakannya fasilitas gerobak sebanyak 30 gerobak. Namun untuk gerobak sendiri banyak pedagang kaki lima yang belum mengetehui hal itu. Jika dilihat dari hasi pernyataan dinas ketersediaan gerobak itu belum ada yang digunakan upaya untuk melakukan penataan yang ada di Jalan Kapten Harun Kabir. Ada salah satu pernyataan dari informan pedagang bahwa pedagang tersebut pernah merasakan fasilitas yang diberikan oleh pemerintah seperti diberikan tenan atau lapak yang disewakan namun hal itu terjadi ketika berjualan di pasar pelita yang sekarang ini sedang dilakukan pembangunan. Pernyataan dari salah satu masyarakat pun ada yang memberi anggapan bahwa fasilitas yang terlihat yang diberikan yaitu adanya tenan atau lapak yang disedikan dipasar-pasar ataupun tempat relokasi.

Terakhir yaitu mengenai prasarana yang diberikan pemerintahan pun telah disedakan namun bisa dilihat kembali bahwa prasarana yang disediakan seperti relokasi di beberapa tempat itu hanya konsen kepada mereka yang berjualan di jalan pelita. Untuk pedagang yang di Jalan Harun Kabir masih belum ada tempat yang optimal untuk dilakukan sebuah strategi penataannya. Selain itu adanya fasilitas seperti tersedianta gerobak untuk pedagang kaki lima itu belum secara menyeluruh diberikan, nyatanya di Jalan Kapten Harun Kabir sendiri tidak ada pedagang kaki lima yang berjualan menggunakan fasilitas gerobak yang disediakan oleh pemerintah daerah. prasarana juga telah disediakan oleh pemerintah daerah, seperti disedikaanya pasar. Karena saat ini pasar sedang dalam proses pembangunan maka dari itu pemerintah menyediakan beberapa tempat relokasi seperti di tipar, di jalan dekat Ramayana dan juga terminal lama yang ad di Jalan Jendral Sudirman. Meskipun bebepa tempat relokasi telah disedikan oleh pemerintah daerah namun pedagang yang berasal dari pasar engga untuk 


\section{ARTIKEL}

di relokasi dan memilih berjualan disekitaran Jalan Kapten Harun Kabir, hal ini tentu menambah volume pedagang kaki lima yang beada disana dan bertambah semerawut. Selain itu pemerintah daerah juga mempunyai beberapa rencana pembangunan tempat berjualan atau pasar. Adapun pasar yang baru-baru ini telah dibangun yaitu Pasar Dewi Sartika.
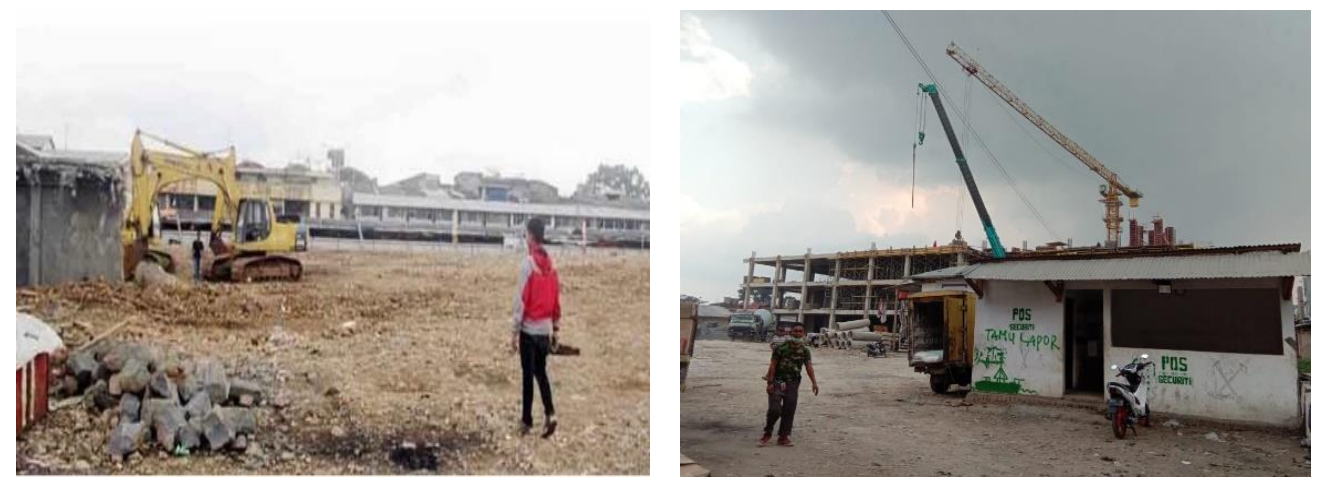

Gambar 2 Proses Pembangunan Pasar Pelita Kota Sukabumi Sumber: Penelitian (2019)

Gambar diatas merupakan proses pembangunan pasar pelita Kota Sukabumi. Dapat dilihat dari gambar diatas bahwa proses pembangunan mempunyai banyak lahan untuk dijadikam tempat berjualan. Maka dari itu perlunya beberapa tempat relokasi di beberapa lokasi pun dibutuhkan tempat yang sesuai dengan volume pedagang yang ada. Namun memang tidak semua pedagang enggan direlokasi bahkan banyak pedagang yang memilih di sekitaran Jalan Kapten Harun Kabir.
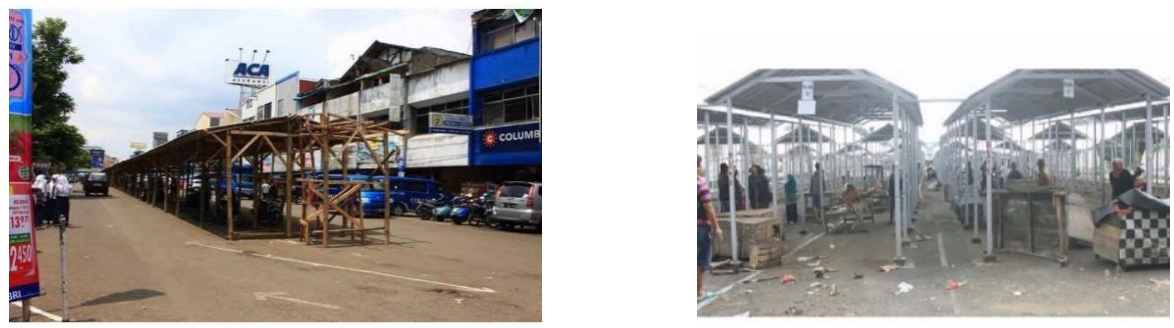

Gambar 3 Tempat Relokasi PKL

Sumber: Pojokjabar.com

Gambar diatas merupakan bangunan atau tempat yang disedikan oleh pemerintah dalam upaya menata pedagang kaki lima yang ada di Jalan Kapten Harun Kabir. Tempat relokasi ini memang di khususkan bagi para pedagang yang berada di pasar pelita karena adanya pembangunan pasar pelita maka para pedagang harus direlokasi dahulu ke tempat yang telah disediakan. Namun sayangnya tidak semua pedagang mau direlokasi. Beberapa pedagang yang enggan direlokasi memilih untuk berjualan disekitaran Jalan Kapten Harun Kabir. Untuk relokasi sendiri termasuk kedalam lokasi pkl yang bersifat sementara dalam 
Perda No. 10 Tahun 2013 pasal 10 ayat (2) merupakan lokasi pkl yang terjadwal dan bersifat sementara.

\section{Dimensi Waktu Keputusan Strategik}

Setiap perencanaan atau pelaksanaan baik itu dalam dana sarana dan prasaranya memiliki jangka waktu tersendiri yang telah ditetapkan. Seperti jangka waktu tempat pedagang yaitu berada di Pasar Pelita yang saat ini sedang dalam proses pembangunan. Namun dalam proses tersebut para pedagang masih ada saja yang enggan untuk dipindahkan relokasi ke tempat yang telah disediakan oleh pemerintah. Pedagang yang engga di relokasi justru kebanyakan memilih berjualan di sekitaran Jalan Kapten Harun Kabir. Jangka waktu untuk relokasi sendiri yaitu sesuai dengan waktu dari proses pembangunan pasar pelita.

\section{Dimensi Orientasi Masa Depan}

Disini sebuah organisasi membutuhkan seorang manajerial handal yang memiliki sikap antisipatif dan proaktif. Karena dengan sikap yang antisifatif dan proaktif, manajemen akan lebih siap menghadapi tanggapan perubahan yang akan terjadi dan tidak akan dihadapkan pada situasi "dadakan". Orientasi masa depan disini maksudnya adalah upaya antisispasi terhadap harapan masa depan yang menjanjikan.

Pemerintah sendiri memiliki perencanaan terkait untuk penataan pedagang kaki lima, rencana yang dibuat oleh pemerintah seperti pembuatan tempat berjualan yang ada di daerah sriwidari, dekat mochi kaswari itu rencana kedepan yang belum terealisasi. Ada pula beberapa rencana yang baru terealisasi yaitu dengan adanya pasar dewi sartika yang baru saja dibangun. Untuk membuat suatu perencanaan pembangunan pasar atau tempat untuk pedagang samapai saat ini selalu memiliki kendala-kendala. Kendala yang utama yaitu di Kota Sukabumi sendiri sulit lahan untuk membangun itu semua. Juga adanya perencanaan yang dibuat oleh pemerintah tentu ada harapan yaitu bisa memberikan fasilitas ataupun kenyamanan berjualan untuk pedagang kaki lima dan juga bisa menata pedagang kaki lima ini agar tidak menggangu hak pejalan kaki. Baik dari pemerintah maupun masyarakat mempunyai harapan yang baik yang sesuai dengan kebutuhan pedagang sebagai salah satu upaya untuk menata pedagang kaki lima agar tidak semerawut. Jika dibandingkan dengan penelitian sebelumnya yang dilakukan oleh Safitri penataan PKL dianggap berhasil sebab dalam upaya penataanya mampu merelokasi pedagang dengan baik dan meningkatkan pendapatan pedagang kaki lima sendiri. Hal tersebut pun bisa dilakukan oleh instansi atau 
pemerintah daerah Kota Sukabumi untuk menapai harapan-harapan tersebut agar bisa menata pedagang kaki lima dengan baik. Kebijakan yang ada semestinya harus dipertegas kembali agar aturan yang ada pun bisa dijalankan sesuai dengan apa yang telah tertulis di dalam Perda Kota Sukabumi No. 10 Tahun 2013.

\section{Dimensi Konsekuensi Isu Strategik Multifaset}

Setiap pembentukan atau pembangunan dalam penataan pedagang kaki lima ini membutuhkan komponen-komponen melihat dari beberapa aspek yang memungkinkan menjadi tempat yang sesuai untu berjualan agar tertata dengan rapi dilihat dari komponen kesesuaian RTRWnya dan juga melihat kondisi lingkungan sekitar. Pernyataan yang disampaikan oleh kedua informan juga sesuai dengan aturan yang ada yaitu bahwa penataam tempat penetapan lokasi pkl harus memperhatikan kepentingan umum, sosial, budaya, estetika, ekonomi, keamanan, ketertiban, kesehatan, kebersihan lingkungan dan sesuai dengan peraturan daerah tentang renana tata ruang wilayah, aturan ini ada dalam Perda No. 10 Tahun 2013 pasal 22 ayat (2).

Tidak hanya unsur dan aspek lain uuntuk bisa menjalankan sebuah strategi namun harus adanya pula sebuah pendataan pedagang kaki lima untuk menjadi acuan dan juga perkembbangan pedagang kaki lima khususnya yang berada di jalan Kapten Harin Kabir. Pendataan untuk pedagang kaki lima itu memang dilaksanakan. Namun saat ini pendataan yang dilakukan belum dilaksakan secara optimal. Seharusnya pendataan ini dilaksanakan setiap tahunnya sebab dalam Perda No. 10 tahun 2013 telah di atur terkait pendataan PKL. Dalam pendataan pkl tersebut ada beberapa tahapan dalam Perda No. 10 tahun 2013 dalam pasal 6 ayat (2) bahwa tahapan pendataan pkl dilakakukan bersama aparat lurah dengan cara, membuat jadwal kegiatan pelaksanaan pendataan, memetakan lokasi, dan melakukan validasi/pemutakhiran data. Selanjutnya dalam pasal 7 pendataan PKL dilakukan berdasarkan identitas PKL, lokasi PKL, jenis tempat usaha, bidang usaha dan modal usaha.

\section{Dimensi Lingkungan Eksternal}

Faktor eksternal juga bisa memberikan dampak dan pengaruh positif ataupun negatif terhadap proses penataan pedagang kaki lima. faktor eksternal yang menghambat proses penataan pedagang kaki lima ada pedagangnya sendiri. Pemerintah daerah telah melakukan berbagai upaya. Upaya saat ini yang ada yaitu melakukan relokasi pedagang dari pasar pelita ke beberapa empa relokasi namun hal ini belum berjalan dengan optimal sebab masih saja 
ada pedang yang enggan direlokasi membuat mereka memilih berjualan disekitaran Jalan Kapten Harun Kabir yang dapat meningkatkan volume pedagang hingga akhinya menjadi semerawut. Selain itu faktor eksternal lainnya yang menghambat proses penataan yaitu adanya oknum-oknum yang tidak bertanggung jawab.

Faktor pendukung strategi Dinas Koperasi, UMKM, Perdagangan dan Perindustrian dalam Penataan Pedagang Kaki Lima di Kota Sukabumi adalah sebagai berikut:

a. Adanya sumber atau dasar hukum yang menjadi pedoman untuk melaksanakan strategi penataan pedagang kaki lima yaitu ada dalam Perda Kota Sukabumi No. 10 Tahun 2013 tentang Penataan dan Pemberdayaan Pedagang Kaki Lima.

b. Adanya program-program yang dibuat dan disediakan oleh pemerintah seperti menfasilitasi sarana dan prasana pedagang kaki lima.

c. Pembangunan dan rencana pembangunan pembuatan pasar dibeberapa daerah.

Sedangkan faktor penghambat strategi Dinas Koperasi, UMKM, Perdagangan dan Perindustrian dalam Penataan Pedagang Kaki Lima di Kota Sukabumi adalah sebagai berikut:

a. Pedagang kaki lima yang berasal dari pasar pelita enggan untuk di relokasi ke tempat yang disediakan, mereka lebih memilih berjualan di sekitaran Jalan Kapten Harun Kabir.

b. Sikap acuh tak acuh dari instansi Dinas Koperasi, UMKM, Perdagangan dan Perindustrian dalam menangani pedagang kaki lima yang semakin banyak.

c. Tidak dilakukan pendataan dalam 2 tahun belakangam ini untuk mengetahui perkembangan pedagang kaki lima yang berada di Jalan Kapten Harun Kabir.

d. Kurangnya sumber daya di Dinas Koperasi, UMKM, Perdagangan dan Perindustrian khususnya di bidang perdagangan dan juga kurangnya sumber daya pegawai yang belum sesuai untuk terjun ke lapangan di Dinas Sat Pol PP juga menjadi faktor penghambat dari penataan pedagang kaki lima.

e. Susahnya lahan di Kota Sukabumi untuk membuat suatu bangunan khusus untuk penataan Pedagang Kaki Lima.

\section{E. KESIMPULAN}

Penataan PKL di Jalan Kapten Harun Kabir Kota Sukabumi belum dilakukan secara optimal, masih banyak kekurangan-kerungan yang terjadi. Peran manajemen puncak belum berjalan secara optimal dikareakan kurangnya sumber daya yang bekerja dilapangan. Sementra itu terkait dimensi alokasi dana, sarana dan prasarana dalam penataan PKL juga 
belum mencapai sasaran. Sementara pada dimensi waktu keputusan strategic, telah sesuai antara teori dan permasalahan sebab setiap perencaan pasti memiliki jangka waktu. Pada dimensi orientasi masa depan, sudah dikatan berhasil namum perencanaan yang dilakukan belum optimal sebab perencanaan penataan PKL tidak hanya berfokus pada PKL yang berada di jalan Harun Kabir. Kosekuensi Isu strategik multifaset, dalam dimensi ini untuk merencanakan strategi penataan PKL yang ada di jalan harun kabir harus melihat dari beberapa aspek, serta sulitnya lahan yang ada di Kota Sukabumi menjadi kendala dalam penataan PKL. Sedangkan terkait dimensi ingkungan ekstrenal sangat mempengaruhi suatu rencana strategi penataan PKL yang berada di jalan kapten harun kabir namun permasalahan yang terjadi yaitu ada pada PKL yang enggan dan masih suit diatur.

\section{DAFTAR PUSTAKA}

Peraturan Daerah Nomor 10 Tahun 2013 Tentang Penataan dan Pemberdayaan Pedagang Kaki Lima Kota Sukabumi.

Permadi, G. (2007). Pedagang Kaki Lima. Jakarta: Yudhistira.

Rachmawati, I. (2018). Pedoman Penelitian Ristik dan Skripsi. Sukabumi: Program Studi Administrasi Publik Fakultas Ilmu Administrasi dan Humaniora.

Sabariah. (2016). Manajemen Strategis. Jakarta: Pustaka Pelajar.

Safitri, N. D. (2015). Analisis Penataan Pedagang Kaki Lima di Kabupaten Maros. Makassar: Skripsi Program Ilmu Pemerintahan. Universitas Hassanudin.

Saladin, D. (2003). Manajemen Strategi \& Kebijakan Perusahaan. Bandung: Linda Karya.

Satori, D. (2011). Metode Penelitian Kualitatif. Bandung: Alfabeta.

Siagian, S. P. (2018). Manajemen Strategik. Jakarta: Bumi Karsa

Sugiyono. (2018). Metode Penelitian Kuantitatif, Kualitatif, dan R\&D. Bandung: Alfabeta.

Sugiyono. (2016). Metode Penelitian Administrasi. Bandung: Alfabeta.

Syawalia, M. N. (2018). Implementasi Kebijakan Tentang Penataan dan Pemberdayaan Pedagang Kaki Lima di Kota Sukabumi. Sukabumi: Skripsi Program Ilmu Administrasi Publik. Universitas Muhammadiyah Sukabumi.

Wahid, Y. (2014). Pengantar Hukum Tata Ruang. Jakarta: Prenada Media Group.

Winardi J. (2003). Entrepeuner \& Entrepreneurship. Jakarta: Prenada Media Group. 